Іван МИКИТА, orcid.org/0000-0002-1778-6148 викладач кафедри мистещьких дисииплін

\title{
СУТНІСТЬ ОРГАНІЗАЦІЇ АНСАМБЛЕВОГО ЗВУЧАННЯ В ОРКЕСТРОВИХ ЖАНРАХ
}

\begin{abstract}
У даному науковому дослідженні висвітлюються питання аналізу сутності організації звучання ансамблю в оркестрових жанрах. Актуальність поданої тематики дослідження зумовлюється стрімким розвитком мистецтвв ансамблевої гри у сучасних умова та необхідністю визначення характерних рис питань організації звучання ансамблю в різноманітних жанрах оркестрової музики. Метою даного дослідження є визначення головних аспектів, щзо мають місце в контексті створення необхідних умов щзодо якісної постановки звучання ансамблів під час виконання музичних творів. Провідним підходом иієї науково-дослідницької роботи є поєднання аналітичного та логічного методів дослідження питань, винесених у заголовок. Виконується глибокий структурний аналіз наукових робіт, доступних у рамках розробки даної тематики дослідження, визначаються типові риси на напрямки проведення досліджень у сфері організаџії звучання ансамблів під час виконання музичних творів, щео було розраховано до оркестрового виконання. Організачія ансамблевого звучання передбачає одночасну участь великої кількості музичних виконавців, щуо потребує напрац̧ювання їхньої злагодженості та вміння своєчасно та якісно виконувати покладені на них функції. Головними результатами цього наукового дослідження стали: визначення основних аспектів організації ансамблевого звучання в жанрах оркестрової музики та констатація наявності типологічних тенденцій у розвитку оркестрового жанру виконання музичних творів у контексті еволючії музичного мистецтвва. Перспективи проведення подальших наукових досліджень у визначеному напрямку полягають у неослабній потребі якісного вивчення різних аспектів музичної культури як невід 'ємної частини загальної культури та необхідності формування методики оцінювання якості виконанні творів музичного мистецттва ансамблями оркестрових типів. Прикладна иінність даної наукової роботи полягає у визначенні ключових аспектів оцінки сутності організаџії звучання ансамблів у жанрах оркестрового мистецтва та можливості втілення у практичній сфері результатів цъього дослідження з метою покращення якості виконання музичних творів ансамблями, щз працюють у різноманітних жанрах оркестрової музики.
\end{abstract}

Ключові слова: оркестрова музика, музична виконавча майстерність, публічні виступи, музичний інтерес. 
Volodymyr SPIVAK, orcid.org/0000-0003-0013-4378

People's Artist of Ukraine,

Senior Lecturer at the Department of Artistic Disciplines

Uzhhorod Institute of Culture and Arts (Uzhhorod,Ukraine)vol.spivak6493-2@uoel.uk

Ivan VARKHOL, orcid.org/0000-0002-6508-0641 Senior Lecturer at the Department of Artistic Disciplines Uzhhorod Institute of Culture and Arts (Uzhhorod,Ukraine)varkhol_i@kpi.com.de

Ivan MYKYTA, orcid.org/0000-0002-1778-6148 Senior Lecturer at the Department of Artistic Disciplines Uzhhorod Institute of Culture and Arts (Uzhhorod, Ukraine) i.mykyta@murdoch.in

\section{THE ESSENCE OF THE ORGANISATION OF ENSEMBLE SOUND IN ORCHESTRAL GENRES}

This study covers the analysis of the essence of the organisation of the ensemble sound in orchestral genres. The relevance of the given subject is conditioned by the rapid development of the art of ensemble performance in modern conditions, and the need to determine the features of the organisation of the ensemble sound in various genres of orchestral music. The purpose of this study is to determine the main aspects that take place in the context of creating the necessary conditions for quality staging of the ensemble sound during the performance of musical works. The leading approach of this study is a combination of analytical and logical methods of research of the subject matter. An in-depth structural analysis of scientific articles available in the development of this subject identifies typical features for research in the field of organisation of ensemble sound during the performance of musical works designed for the orchestra. The organisation of ensemble sound involves the simultaneous participation of a large number of musical performers, which requires the need to develop their coherence and the ability to timely and efficiently perform their functions. The main results of this study included: identification of the main aspects of the organisation of ensemble sound in the genres of orchestral music and the establishment of typological trends in the development of the orchestral genre of musical works in the context of the evolution of musical art. Prospects for further research in this area include the constant need for quality study of various aspects of music culture as an integral part of general culture and the need to develop a methodology for evaluation of the quality of musical works by ensembles of orchestral types. The applied value of this study is to identify key aspects of evaluating the essence of the ensemble sound in the genres of orchestral art, and the possibility of implementing the results of this study in practice in order to improve the performance of musical works by ensembles working in various genres of orchestral music.

Key words: orchestral music, musical performing skills, public performances, musical interest.

Постановка проблеми. Ансамблеве виконання музичних творів потребує якісної організації та постанови гри колективу музикантів, а також неабиякої виконавчої майстерності з їхнього боку. На початку XIX століття завдяки сформованому великому репертуару музичний ансамбль утвердився як повноправна самостійна форма музикування. У даний період значного поширення набула традиція домашнього музикування: соло, виконання музичних творів у різних ансамблях, акомпанемент співу, танців і т.д. Твори для виконання в чотири руки, розраховані на середній піаністичний рівень, були доступні багатьом любителям. 3'явилися перші перекладання оркестрових творів, що дозволило любителям музики познайомитися із творами різних жанрів та стилів виконання (Горбунова, 2010: 277).

Творчий шлях ансамблю будь-якого сценічного та оркестрового жанру не слід починати 3 роботи над творами класичного стилю. Зовнішня доступність, ілюзія технічної простоти таять у собі небезпеку зниження високохудожньої цінності та змістовності, що є властивими музиці цього, дуже високого, рівня. Виконання, наприклад, фортепіанних ансамблів Вольфганга Амадея Моцарта вимагає тонкого смаку, розвиненої пальцевої техніки, вишуканої майстерності гри на фортепіано та рідко вдається студентам на стадії початкового навчання ансамблевої гри. Водночас загально-музична ерудиція студентів дозволяє 
порівняно вдало розпочати вивчення фортепіанного ансамблю на репертуарі сучасних російських i зарубіжних композиторів, наприклад, сонати Франсіса Пуленка, «Скарамуш» та «Каприччіо» Даріуса Мійо, «Маленька сюїта» Клода Дебюссі, «Рондо» Миколи Черепніна, сім п’єс 3 «Мікрокосмосу» Бели Бартока тощо (Мищенко, 2018: 24). До того ж слід відзначити різний рівень здібностей виконавців музичних творів та їхню здатність підтримувати високу якість гри під час сценічного виконання, що також потребує наполегливого напрацювання та удосконалення.

Аналіз досліджень у сфері сутності організації ансамблевого звучання в різних оркестрових жанрах свідчить про те, що після закінчення Другої світової війни була відмічена тенденція до початку відродження різноманітних оркестрових жанрів у музичному виконавському мистецтві (Кирилов, 2009а: 1360). Концертне життя все більше тяжіло до форм музичних зборів, що все частіше влаштовувалися в музеях, картинних галереях, у знову відбудованих малих залах (Горбунова, 2010: 278). Усе це мало величезний вплив на процеси становлення та розвитку мистецтва організації ансамблевого звучання в різних оркестрових жанрах, що загалом сприяло розвитку музичної культури в цілому (Сичугов, 2015: 263).

Стосовно сутності організації ансамблевого звучання щодо виконання музичних творів естрадно-духовими оркестрами, то слід зазначити, що на період 1920-1930 рр. контакти вітчизняної академічної музики й джазу не були настільки різноманітними, як, наприклад, у США та деяких західноєвропейських країнах, а мали скоріше епізодичний характер. Нечисленність експериментів радянських композиторів у досить туманному жанрі зумовлена низкою факторів - як музичного, так і поза музичного характеру. Головними 3 них виступають недостатня ступінь інформованості та сумнівна художня цінність тих зразків, за якими вітчизняні автори знайомилися із джазом та іншими жанрами естрадно-духової оркестрової музики (Балин, 2008: 212).

Загалом навколо різноманітних стилів естрадно-духової оркестрової музики у середині XX століття розгорнулася широка дискусія. Перші теоретичні уявлення щодо зовнішнього обліку радянського джазу та міркувань щодо того, яким він має бути, з'явилися у збірнику «Джаз банд та сучасна музика» (1926 рік). Але в дискуciï, що мала місце в СРСР, була своя специфіка. Якщо в Свропі джаз викликав найзапекліший опір вкрай правих громадських груп (націонал-соціалістів, радикальних діячів церкви, в основному римсько-католицької), то на теренах Росії даний жанр ініціював обурення вкрай лівих угруповань (в їх числі РАПМ) (Балин, 2008: 211). Із часом теоретичні спори плавно перейшли до політичної плоскості. Таким чином, мистецтво естраднодухового виконання оркестрової музики на теренах колишнього СРСР мало дуже непростий шлях визнання та теоретичної й практичної оцінки його сутності з різних точок зору (музичної, політичної, ідеологічної тощо).

Слід зауважити, що основним завданням художньої творчості декларувалася пропаганда життєвих основ радянського ладу і його політики. Головним засобом вирішення даної задачі «пролетарські музиканти» вважали пісню. Причому все інші жанри автоматично потрапляли до розряду несоціалістичного мистецтва (Балин, 2008: 211). Загалом стосовно різних аспектів сутності організації ансамблевої гри та звучання ансамблю в оркестрових жанрах слід зауважити, що протягом усього XX століття теоретичні та практичні уявлення щодо засобів організації ансамблевого звучання постійно змінювалися, чому сприяв активний розвиток різних оркестрових жанрів. Цьому сприяло зростання виконавчої майстерності музикантів, розвиток системи музичної освіти на теренах колишнього СРСР та у світі в цілому. Глибоке та систематичне вивчення різноманітних аспектів цього питання має сприяти подальшому розташуванню акцентів щодо широкого кола питань, пов'язаних з організацією ансамблевого звучання стосовно музичних колективів жанру естраднодухового оркестру та інших напрямів та жанрів оркестрової музики (Данилова, 2018: 132-133).

Мета даного дослідження полягає у визначенні основних аспектів сутності організації ансамблевого звучання стосовно історії розвитку традицій наявних оркестрових жанрів. Задля досягнення цієї мети виконується загальне дослідження історії розвитку жанрів оркестрової музики у XX-му та на початку XXI століття та підбиваються найбільш суттєві підсумки цього процесу.

Виклад основного матеріалу. Вже на початку XIX століття музичний ансамбль завдяки сформованому репертуару міцно затвердився як повноправна самостійна форма музикування. На цей проміжок часу вельми великі масштаби прийняло розповсюдження культури домашнього музикування, соло, виконання музичних творів у різних ансамблях, створення якісного акомпанементу співу, танцям та ін. Твори для виконання в чотири руки, розраховані на середній піаністичний рівень, були доступні багатьом любителям. 3'явилися перші перекладання оркестрових 
творів, що дозволило любителям музики познайомитися із творами різних жанрів та стильових напрямків (Кирилов, 2009: 1069).

Активний розвиток різноманітних жанрів оркестрової музики в колишньому Радянському Союзі зокрема та у світі в цілому, починаючи 3 1920-1930 рр. минулого століття, викликав необхідність у формуванні необхідних умов щодо якісної оцінки організації звучання ансамблевих колективів у контексті їх виконання музичних оркестрових творів. Наявні на цей проміжок часу музичні колективи пройшли неабиякий шлях творчих пошуків та вдосконалення майстерності, визнання їхньої манери виконання музичних творів та їхнього права на існування у єдиній системі музичних цінностей загалом. Стосовно розвитку музичного мистецтва естрадно-духових оркестрів слід зазначити, що саме у XX столітті мало місце активне розповсюдження джазової музики, починаючи 3 моменту зародження джазу на теренах США (Малиновська, 2017: 15-16). Джаз виник як наслідок поєднання традицій європейської та афроамериканської музики. Спочатку цей музичний напрямок був виключно імпровізаційним (новоорлеанський стиль, диксиленд), але згодом, у зв'язку зі збільшенням інтересу до цієї музики білого населення, професіоналізацією музикантів-джазменів, а також за рядом причин іншого характеру у джазовій музиці збільшилося значення якісної аранжування й композиції, що не виходять при цьому за межі джазової музики.

Головним аспектом музики джазового ансамблю, що суттєво відрізняє його від інших музичних напрямків, $\epsilon$ його звучання, а точніше - зовсім інша манера використання музичних інструментів (Гажим, Гранецька, 2018: 133). Мистецтво гри естрадно духового-джазового оркестру, що накладає певний відбиток на аспекти організації його звучання, полягає в суттєвій різниці підходів до постановки самого процесу гри, який має величезні відмінності від постановки гри в багатьох інших жанрах мистецтва оркестрової музики. Джазовий підхід до інструменту докорінно відрізняється від звичайного. Всупереч загальноприйнятій думці, що музика визначає інструментування, у джазі характер музики визначає інструмент (Беговатова, 2011: 214).

Використання музичного інструменту під час виконання музичних творів здебільшого вражає слухача почуттям «різкості» та «грубості», а подекуди й «брутальності». Це при тому, що самим фактом свого народження джаз зобов'язаний своєму головному чиннику - джазовій експресії. Сутність організації ансамблевого звучання стосовно мистецтва гри на інструментах естрадно-духового оркестру полягає в наданні суттєвої уваги таким чинникам:

- якісний підбір аранжування, що забезпечує потрібний рівень сприйняття виконання музики слухачами;

- злагодженість у виконанні музичних творів усіма виконавцями ансамблю, що досягається багатьма годинами сумісних музичних занять;

- неухильне зростання виконавчої майстерності усіх виконавців загалом, що забезпечую загальне зростання якості виконання музичних композицій та значно полегшує питання організації ансамблевого звучання.

У контексті впливу питань організації ансамблевого звучання на розвиток музичних оркестрових жанрів слід зазначити, що саме духова естрадна музика мала великий вплив на становлення різноманітних традицій академічного музичного мистецтва. Наприклад, у США у середині XX століття оперне виконання можна було почути набагато рідше в порівнянні 3 композиціями естрадно-духової музики, це при тому, що оперні вистави почали даватися у країні ще починаючи з 1865 року (Малиновська, 2017: 30-31). На той час в США були створені також при професійних академічних оркестри. Однак лише один iз них, бостонський симфонічний оркестр, який користувався підтримкою Генрі Лі Хіггінсона, був практично незмінною організацією, мав контракт на повний сезон, проводячи регулярні репетиції, та міг присвятити себе виключно виконанню симфонічної музики.

Як було підкреслено вище, велике значення в контексті організації ансамблевого виконання має забезпечення належного рівня виконавчої майстерності музикантів. Особливо це стосується музикантів, що грають на духових інструментах та $є$ членами колективів естрадно-духових оркестрів. Варто зазначити, що професійна майстерність музиканта, що грає на духовому інструменті, завжди має на увазі технічно вчинене й художньо виправдане відтворення музичного твору, ансамблевої та оркестрової партії.

Для цього виконавський багаж професіонала повинен містити широкий набір (комплекс) технічних прийомів та способів, а також інтонаційновиразних засобів і ефектів виконання. Поступове зростання виконавчої майстерності музикантів-дубовиків зумовлює спрощення організації ансамблевого звучання стосовно естрадно-духового жанру оркестрової музики, що, у свою чергу, створює умови для подальшого розвитку цього напрямку оркестрової музики в цілому. На тепе- 
рішній час відбувається поступове поширення інтонаційно-виразних засобів й ефектів виконання музичних творів, що активно сприяє зростанню потреб до рівня реального розвитку майстерності виконавців. Сьогодні проблеми якісного формування техніки виконання та організації виступу духових оркестрів повною мірою постають як перед самими музичними виконавцями, так i перед педагогами музичних фахів на етапах підготовки у вищих навчальних музичних закладах.

Організація ансамблевого звучання незалежно від оркестрового жанру, до якого належить цей ансамбль, вимагає від його керівників неабияких педагогічних здібностей та проявів організаційного таланту. Адже виконавці найчастіше відрізняються один від одного за характеристиками та рівнем майстерності, тому саме від керівника остаточно залежить якість постановки та виконання музичного твору, а також мікроклімат у колективі та результати сумісної праці його членів.

Індивідуальні заняття мають у даному аспекті величезне значення. Одна 3 головних завдань занять 3 початківцями - це розвиток у них музичного уяви, що включає асоціативні уявлення про різноманітні звучання, присутні в навколишньому світі. Розвиток асоціативних музичних вистав може бути заснований на виконанні окремих завдань: імітування звуків, характерних для удару годинника, співу зозулі, відтворення ефектів луни і т.д. Тим самим музичний виконавець втягується в активний творчий процес, зумовлений реалізацією образних асоціацій у звучанні інструменту. Використовуючи у виконанні завдань даного типу найрізноманітніший матеріал, керівник ансамблевого колективу може імпровізувати, спираючись на особистий музично-виконавський досвід. Після виконання підготовчих завдань можна переходити до репертуару, виконавцеві доступному, й відповідному рівню музичного розвитку окремих членів колективу (Анисимов, 2014: 187).

Організація підготовки музичного ансамблевого колективу до виконання музичних творів на публічних виступах має плануватися керівником 3 урахуванням поступового розвитку майстерності виконавців. Феномен авторської виконавської редакції також може бути пов'язаний із багатством закладеного потенціалу у структурі твору, проявом не помічених раніше виразних елементів та аспектів музичної логіки. Саме так і відбувається формування організаційної структури звучання ансамблю любого без винятку оркестрового жанру. Теоретично наявність різноманітних зв'язків проміж компонентами організації звучання ансамблів різних жанрів оркестрового вико- нання зумовлює поступове зростання якості такої організації як такої, що враховує взаємозв'язки між різними етапами підготовки музикантів. У злагодженій схемі цього процесу виконавська техніка може характеризуватися як самостійна та незалежна від вищих детермінант категорія, як іманентна сукупність рухових прийомів та навичок, які, об'єднуючись за функціональними ознаками, в кінцевому рахунку сприяють отриманню необхідного результату, що виявляється в досягненні необхідного рівня оркестрової взаємодії між усіма учасниками оркестрового виконання музичного твору (Анисимов, 2015: 272-273).

Слід зауважити, що в контексті організації ансамблевого звучання не слід ототожнювати процес виконання музичного твору із творчим процесом (Князев, Князева, 2019: 100). Творчість окремих виконавців $є$ процесом духовної діяльності окремого виконавця, прояву рівня розвиненості його музичного мислення та можливостей особистої інтерпретації музичного твору. Творчій процес є неможливим без чіткої фіксації навичок виконання музичних творів та автоматизованих навичок, моторики та інших рефлекторних дій (Смурова, 2010: 50). Невипадково у професійному побуті музикантів $\epsilon$ крилата фраза «Шукай образ - знайдеш техніку».

Таким чином, сутність організації ансамблевої гри в рамках наявних жанрів оркестрового мистецтва являє собою вельми складне завдання, від якісного та своєчасного розв'язання якого залежить не тільки звучання окремого ансамблю під час виконання певного музичного твору, а навіть послідовність розвитку культури музичного виконання творів музичного мистецтва як в окремих оркестрових жанрах, так і загалом стосовно розвитку окремих музичних напрямків. Отже, завдання організації ансамблевого звучання потребує послідовного вирішення багатьох питань, пов'язаних із розвитком культури музичного виконання, підвищенням виконавчої майстерності музикантів, а також формуванням умов, необхідних для поступового зростання та розвитку музичної культури в цілому. Музика є одним iз найдавніших різновидів мистецтва, що поступово еволюціонує протягом свого існування, тому питання організації різноманітних аспектів творчості в даній сфері мають суттєве значення в контексті розвитку як самої музичної культури, так i культури людства загалом.

Висновки. Аналіз різноманітних аспектів сутності організації ансамблевого звучання в оркестрових жанрах призвів до таких висновків. Сутність організації ансамблевого звучання 
в оркестрових жанрах полягає у своєчасному поєднанні багатьох складових частин, серед яких найважливіше місце відводиться якості аранжування музичного твору, розвинутій виконавчій майстерності та злагодженому виконанню ансамблем музичних творів, що складають основу його репертуару. Якісне поєднання усіх цих факторів досягається за рахунок наполегливої праці усіх без винятку ланок, що складають структуру музичного колективу. Крім того, варто відзначити, що гра у складі будь-якого ансамблю вже є підтвердженням факту досягнення музикантом певного ступеню музичної майстерності, тому що ансамблева гра є найпопулярнішою формою музикування 3 багатовіковою історією. Музичні інструменти у своєму ансамблевому розмаїтті створюють відчуття свободи та відвертості виконання музичного твору, забезпечують його відображення в широкому відображенні звукових тональностей.

Творче спілкування музикантів-ансамблістів також сприяє зростанню ініціативності й більш жвавому інтересу до питань інтерпретації музичних творів, що виконуються. Нові вимоги пред'являються до виконавської волі, концентрується увага виконавців, формується якісно нове уявлення про свободу виконання, про прояву творчої індивідуальності, про професійну відповідальність. Спільна праця активізує роботу думки та фантазії членів музичного колективу, сприяючи в кінцевому підсумку розвитку самостійності мислення та манери виконання музичних творів. Систематичні заняття ансамблем сприяють не лише професійному, але й моральному розвитку члена музичного ансамблю. Причина настільки глибокого впливу полягає у специфіці самої форми спільного музикування. Музичний ансамбль $є$ якимось єдиним цілим, єдиним організмом, наділеним власним пульсом, диханням, уявою, станом причетності до творчості. На відміну від індивідуальності соліста, яка $є$ його надбанням, творча індивідуальність ансамблю є результатом органічного синтезу багатьох окремих індивідуальностей, що досягається усвідомленим самообмеженням виконавського «я».

Таким чином, питання організації ансамблевого звучання в контексті діяльності музичних колективів різноманітних оркестрових жанрів зберігають свою актуальність на теперішньому етапі розвитку світової культури та музикального мистецтва. Подальші дослідження у цій сфері допоможуть виявленню нових аспектів цього питання, що має позитивно сказатися на всьому подальшому розвитку мистецтва оркестрового виконання та сприяти покращенню умов цього розвитку, що буде мати неабияке значення для вдосконалення культури оркестрового виконання у світі в цілому.

\section{СПИСОК ВИКОРИСТАНИХ ДЖЕРЕЛ}

1. Анисимов М. В. Исполнительская техника музыканта-духовика. Вестник Московского государственного университета культуры и искусств. 2014. № 5(61). С. 186-171.

2. Анисимов М. В. Исполнительское мастерство как интегральное индивидуально-творческое качество музиканта-духовика. Гуманитарные, социально-экономические и общественные науки. 2015. № 5. С. 271-275.

3. Балин А. П. Духовой оркестр и формирование традиции джазового оркестрового исполнения в России. Becmник Московского государственного университета культуры и искусств. 2008. № 5. С. 211-214.

4. Беговатова М. А. Система исполнительского процесса музыканта-духовика. Вестник Московского государственного университета культуры и искусств, 2011. № 5(43). С. 213-216.

5. Гажим И. А., Гранецька Л. В., Інтерпретація музичного образу як методична проблема. Музичне мистецтво та oсвima, 2018. № 4. C. 132-144.

6. Горбунова И. В. Ансамблевое музицирование как компонент содержания профессиональной деятельности будущего педагога-музыканта. Вестник Костромского государственного университета, 2010. № 3. С. 276 -281.

7. Данилова О. С. Вивчення авторських інтерпретацій як один із напрямів роботи в класі фортепіано: на прикладі творчої спадщини М. К. Метнера. Музичне мистецтво та освіта, 2018. № 3. С. 129-146.

8. Кирилов С. В. Проблема музикального мышления в контексте исполнительной деятельности музиканта-духовика. Вести Самарского научного иеетра Российской академии наук, 2009а. № 4(5). С. 1357-1363.

9. Кирилов С. В. Особенности формирования художественного образа в аспекте интерпретации музикального произведения. Вести Самарского научного иентра Российской академии наук, 2009b. № 4(4). С. 1068-1071.

10. Князев А. М., Князева Н. А. Роль музикального анализа в технологии раскрытия художественно-музыкального образа в произведениях при игре на баянне и аккордеоне. Вестник Кемеровського государственного университета культуры и искусств, 2019. № 47. С. 98-104.

11. Малиновська А. В. Індивідуальність та індивідуальний стиль виконавця як категорії теорії виконавства й педагогіки музичної освіти. Музичне мистеитво та освіта, 2017а. № 4. С. 13-27.

12. Малиновська А. В. Інтерпретаційний та класифікаційний аспекти вивчення виконавських стилів в працях вітчизняних дослідників фортепіанного мистецтва. Музичне мистецтво та освіта, 2017. № 3. С. $27-41$.

13. Мищенко М .Ю. Деякі особливості сучасного ансамблевого виконавства в курсі загального фортепіано. Педагогіка. Питання теорії та практики, 2018. № 3(11). С. 22-25. 
14. Сичугов А. М. «Художественная техника» в теории исполнительства на духовых инструментах: искусствоведческий аспект. Вестник Московского государственного университета культуры и искусств, 2015. № 2(64). C. $260-265$.

15. Смурова Д. А. Джазова культура суспільства. Аналітика культурологї, 2010. № 6. С. 50-54.

\section{REFERENCES}

1. Anisimov M. V. Ispolnitelskaya tehnika muzyikanta-duhovika [Performing technique of the musician-woodwind]. Vestnik Moskovskogo gosudarstvennogo universiteta kulturyi i iskusstv, 2014, Nr 5 (61), pp. 186-171 [in Russian].

2. Anisimov M. V. Ispolnitelskoe masterstvo kak integralnoe individualno-tvorcheskoe kachestvo muzikanta-duhovika [Performing skills as an integral individual and creative quality of the musician-brass player]. Gumanitarnyie, sotsialno-ekonomicheskie i obschestvennyie nauki, 2015, Nr 5, pp. 271-275 [in Russian].

3. Balin A. P. Duhovoy orkestr i formirovanie traditsii dzhazovogo orkestrovogo ispolneniya v Rossii [Brass band and the formation of the tradition of jazz orchestral performance in Russia]. Vestnik Moskovskogo gosudarstvennogo universiteta kulturyi i iskusstv, 2008, Nr 5, pp. 211-214 [in Russian].

4. Begovatova M. A., Sistema ispolnitelskogo protsessa muzyikanta-duhovika [System of the performing process of the musician-windmaker]. Vestnik Moskovskogo gosudarstvennogo universiteta kulturyi i iskusstv, 2011, Nr 5 (43), pp. 213-216 [in Russian].

5. Gazhim I. A., Granetska L. V. InterpretatsIya muzichnogo obrazu yak metodichna problema [Interpretation of the musical image as a methodological problem]. Muzichne mystetstvo ta osvita, 2018, Nr 4, pp. 132-144 [in Ukrainian].

6. Gorbunova I. V. Ansamblevoe muzitsirovanie kak komponent soderzhaniya professionalnoy deyatelnosti buduschego pedagoga-muzyikanta [Ensemble music making as a component of the content of professional activity of the future teacher-musician]. Vestnik Kostromskogo gosudarstvennogo universiteta, 2010, Nr 3, pp. 276-281 [in Russian].

7. Danilova O. S. Vivchennya avtorskih InterpretatsIy yak odin iz napryamIv roboti v klasI fortepIano: na prikladi tvorchoyi spadschini M. K. Metnera [The study of author's interpretations as one of the areas of work in the piano class: on the example of the creative heritage of M. K. Mettner]. Muzychne mystetstvo ta osvita, 2018, Nr 3, pp. 129-146 [in Ukrainian].

8. Kirilov S. V. Problema muzikalnogo myishleniya v kontekste ispolnitelnoy deyatelnosti muzikanta-duhovika [The problem of musical thinking in the context of the performance of a wind musician]. Vesti Samarskogo nauchnogo tsentra Rossiyskoy akademii nauk, 2009a, Nr 4 (5), pp. 1357-1363 [in Russian].

9. Kirilov S. V. Osobennosti formirovaniya hudozhestvennogo obraza v aspekte interpretatsii muzikalnogo proizvedeniya [Features of the formation of the artistic image in the aspect of interpretation of a musical work]. Vesti Samarskogo nauchnogo tsentra Rossiyskoy akademii nauk, 2009b, Nr 4 (4), pp. 1068-1071 [in Russian].

10. Knyazev A. M., Knyazeva N. A. Rol muzikalnogo analiza v tehnologii raskryitiya hudozhestvenno-muzyikalnogo obraza v proizvedeniyah pri igre na bayanne i akkordeone [The role of musical analysis in the technology of disclosure of artistic and musical image in works when playing the accordion and accordion]. Vestnik Kemerovskogo gosudarstvennogo universiteta kulturyi i iskusstv, 2019, Nr 47, pp. 98-104 [in Russian].

11. Malinovska A. V. Individualnist ta individualnuy styl' vykonavtsya yak kategoriyi teoriyi vykonavstva i pedagogiky muzichnoyi osvity [Individuality and individual style of the performer as a category of performance theory and pedagogy of music education]. Muzychne mystetstvo ta osvita, 2017a, Nr 4, pp. 13-27 [in Ukrainian].

12. Malinovska A. V. Interpretatsiyni ta klasyfikatsiyni aspekty vyvchennya vikonavskyh styliv v pratsyah vitchyznyanyh doslidnykiv fortepiannogo mystetstva [Individuality and individual style of the performer as a category of performance theory and pedagogy of music education]. Muzychne mystetstvo ta osvita, 2017b, Nr 3, pp. $27-41$ [in Ukrainian].

13. Mischenko M. Yu. DeyakIi osoblyvosti suchasnogo ansamblevogo vykonavstva v kursi zagalnogo fortepiano [Some features of modern ensemble performance in the course of general piano]. Pedagogika. Pytannia teoriyi ta praktyky, 2018, Nr 3 (11), pp. 22-25 [in Ukrainian].

14. Sichugov A. M. «Hudozhestvennaya tehnika»v teorii ispolnitelstva na duhovyih instrumentah: iskusstvovedcheskiy aspekt ["Art technique" in the theory of performance on wind instruments: art aspect]. Vestnik Moskovskogo gosudarstvennogo universiteta kulturyi i iskusstv, 2015, Nr 2 (64), pp. 260-265 [in Russian].

15. Smurova D. A. Dzhazova kultura suspilstva [Jazz culture of society]. Analityka kulturolohiyi, 2010, Nr 6, pp. 50-54 [in Ukrainian]. 